СЕМАНТИЧНО-ЕТИМОЛОГІЧНИЙ АНАЛІЗ ПРОФЕСІЙНОЇ ІДЕНТИЧНОСТІ МАЙБУТНІХ БАКАЛАВРІВ ІНОЗЕМНОЇ МОВИ ЯК ФІЛОСОФСЬКОЇ I ПСИХОЛОГО-ПЕДАГОГІЧНОЇ КАТЕГОРІЇ

\title{
SEMANTIC-ETHIMOLOGICAL ANALYSIS OF PROFESSIONAL IDENTITY OF FUTURE BACHELORS IN FOREIGN LANGUAGES AS A PHILOSOPHICAL AND PSYCHOLOGICAL-PEDAGOGICAL CATEGORY
}

УДК:81'23:811.111

DOI https://doi.org/10.32843/2663-60852019-19-1-15

\section{Гнатик К.Б.,}

аспірант касредри англійської фрілології та методики викладання іноземних мов Мукачівського державного університету, асистент

Закарпатського угорського інституту імені Ференца Ракоці II у статті виконано семантично-етимологічний аналіз професійної ідентичності як фрілососьської і психолого-педагогічної категорії. Установлено, що усвідомлення належності до певної професії, яке формується в прочесі професійної підготовки, визначається як професійна ідентичність. Узагальнено теоретичне осмислення дослідження ідентичності, що базується на наявних напрацюваннях у різних царинах гуманітаристики. Історична еволюція проблематики ідентичності на різних їі рівнях простежується у фрілософрських, психологічних і соціологічних наукових розвідках. Проаналізовано різноманітні підходи до тлумачення категорій «ідентичність», «профресійна ідентичність». Резюмовано, що етимологічно поняття «ідентичність» походить від латинського слова «identicus» та означає «тотожність, збіг двох предметів або понять».

Теоретичний аналіз використання поняття «ідентичність» дав змогу трактувати розуміння ідентичності як френомена, що має динамічний і структурний характер, пов'язаний із безперервним процесом розвитку особистості. Аналізуючи проблему ідентичності, по-перше, необхідно враховувати, що формування ідентичності $\epsilon$ взаємопов'язаною сукупністю виборів, за допомогою яких особистість приймає особисті иілі, иінності, переконання. По-друге, розвиток ідентичності не є лінійним процесом, оскільки може розвиватися в прогресивному та регресивному напрямах. I, по-третє, ідентичність розвивається протягом усього життя.

Констатовано, що в межах міждисциплінарних досліджень ідентичність розглядається як константність, тотожність особистості, у якій є три ключові складники: психофрізіологічна ідентичність; соціальна ідентичність; особиста ідентичність (або егоідентичність). З'ясовано, що в теорії та методології антропології профресійна ідентичність розглядається як основа самосвідомості членів професійних груп і спрямовується на вивчення життєвого світу профресіоналів «зсередини», на дослідження прихованих особистісних і соціальних процесів, специфріки життєвого світу й ідентич- ності суб'єктів, що виконують специфрічну професійну функцію.

Ключові слова: ідентичність, просресійна ідентичність, самоідентифікація, майбутні бакалаври іноземної мови.

The article defines a semantic-etymological analysis of professional identity as a philosophical and psychological-pedagogical category. It is established that the awareness of belonging to a particular profession, which is formed in the process of professional training, is defined as professional identity. Theoretical comprehension of identity research is based on the existing developments in various fields of humanities. The historical evolution of identity at its various levels is traced in philosophical, psychological, and sociological works, various approaches to interpreting the categories "identity", "professional identity" are analyzed. It is summarized that the etymological term "identity" comes from the Latin word "identicus" and means "identity, coincidence of two objects or concepts".

A theoretical analysis of the use of the concept of "identity" interprets the understanding of identity as a phenomenon that has a dynamic and structural nature associated with the continuous process of personality development. Analyzing the problem of identity, firstly, it must be stated that identity formation is an interconnected set of choices whereby a person accepts his or her personal goals, values, and beliefs. Secondly, identity development is not a linear process, as it can progress in progressive and regressive directions. And thirdly, identity develops throughout life. It is stated that in the framework of interdisciplinary research identity is considered as a constancy, an identity of a personality, which has three key components: psychophysiological identity, social identity and personal identity (or self-identity). It is established that in the theory and methodology of anthropology professional identity is considered as the basis of self-consciousness of members of professional groups and is directed to the study of the lifeworld of professionals "from within", to the study of hidden personal and social processes, the specifics of the lifeworld and identity of persons who perform a specific professional function.

Key words: identity, professional identity, selfidentification, future bachelors in foreign languages.
Постановка проблеми в загальному вигляді. Профресійний розвиток майбутніх бакалаврів іноземної мови передбачає цілковите занурення студентів у виконання професійних обов'язків та усвідомлення власного місця в системі міжособистісних взаємин колективу й системі професійного простору загалом. Усвідомлення належності до певної професії, що фрормується в процесі профресійної підготовки, визначається як професійна ідентичність. Найважливішу роль у професійному розвитку майбутніх бакалаврів іноземної мови відіграють діяльність і спілкування, що реалізуються в межах роботи за фрахом. Психологічно грамотне й обґрунтоване, комплексне й водночас індивідуалізоване навчання є одним із найсильніших і керованих чинників, що перебувають в основі активного фрормування професійної ідентичності майбутніх бакалаврів іноземної мови. 
Науковий інтерес до процесів ідентиорікації, становлення власної ідентичності як базової форми відповідальності особистості зумовлений соціальними змінами в сучасній ситуації розвитку суспільства, пов'язаними зі стратегічним курсом держави на інноваційний розвиток, коли значно розширюються горизонти й підвищується рівень особистісної відповідальності людини. Саме процеси самоідентифрікації $€$ системотвірним чинником у забезпеченні стійкості буття особистості в мінливому багатовимірному світі, розглядають становлення ідентичності як умову існування й розвитку індивіда.

Аналіз останніх досліджень і публікацій. Проблема ідентичності окреслювалася ще в глибоку давнину античними фрілософрами (Сократ, Аристотель, І. Кант). Як самостійна фрілософська проблема ідентичність починає вперше розроблятися в XVII-XVIII століттях на Заході (Д. Локк, Д. Юм). Філософи розглядали означену проблему з погляду її змісту та критеріїв. Із терміном «ідентичність» тісно пов'язане поняття «ідентиорікація», яке вперше використане 3. Фрейдом на межі XIXXX ст. і трактувалося як механізм взаємодії між особистістю й соціальною групою. Зарубіжні вчені Е. Фромм, С. Хантінгтон, К.-Г. Юнг розглядали ідентифрікацію як адаптацію, пристосування до життєвих умов. У 70-х рр. XX ст. термін «ідентичність» починає розглядатися 3 погляду психології як один із чинників розвитку «понад Я» (Е. Еріксон, А. Фрейд).

У другій половині XX ст. ідентичність визначають у двох різних значеннях. 3 одного боку, ідентичність $€$ тією ознакою, що спочатку присутня в житті суб'єкта (Е. Еріксон, В. Хесле, Г. Люббе), вона передбачає своє розширення й поповнення новим змістом на різних етапах життєдіяльності людини. В іншому випадку ідентичність розглядається як щось непостійне, те, що знаходиться й підтримується, виходячи з міркувань затребуваності й корисності (П. Бергер, Т. Лукман, 3. Бауман).

Проблема професійної ідентичності вперше стала вивчатися 3 виникненням системи професійного навчання. Зарубіжні психологи активно вивчали проблему формування профресійної ідентичності (Е. Еріксон, П. Бергер, Т. Лукман, Д. Сьюпер) і вважають, що під час становлення профресійної ідентичності людина проходить ті ж етапи, що й під час соціалізації. Когорта дослідників (Ю. Кухарчук, Е. Шорохова, А. Гузь, Е. Трандіна, Л. Федотова) зараховують професійну ідентичність до предмета дослідження педагогіки, вважаючи, що професійна ідентичність фрормується в результаті професійного навчання, професійного виховання й самовиховання. Інші науковці (Е. Єрмолаєва, К. Альбуханова-Славська, Є. Шорохова, Е. Климов та ін.) пов'язують проблему професійної ідентичності з вивченням життєвих цілей і планів осо- бистості в профресійній сорері, фрормування якої $€$ результатом особистісного та професійного розвитку, що виявляється на досить високих рівнях оволодіння профресією.

Процес фрормування професійної ідентичності в умовах фрілологічної освіти досліджували сучасні науковці (С. Тормасін, Н. Пучков, Е. Мирський, Н. Радіонова та ін.). Вивченням ролі й місця іноземної мови в такому процесі займалися дослідники А. Вербицький, Н. Хомякова, Г. Лаврентьєв, Г. Дубініна, котрі стверджують, що тільки в умовах міждисциплінарної взаємодії фрормуються різноманітні навички професійної іншомовної комунікації; оволодіння професійно орієнтованою іноземною мовою стимулює розвиток у студентів пізнавального інтересу до професійної діяльності, усвідомлення особливостей своєї майбутньої спеціальності, що загалом фрормує професійну ідентичність.

Виділення не вирішених раніше частин загальної проблеми. Незважаючи на велику кількість досліджень, присвячених проблемі фрормування професійної ідентичності, а також ролі й місця іноземної мови в цьому процесі, дотепер процес фрормування означеного феномена в майбутніх бакалаврів іноземної мови не до кінця усвідомлений і належить до одного з найменш розроблених аспектів педагогічної та психологічної теорії і практики.

Тому метою статті визначено семантичноетимологічний аналіз професійної ідентичності як фрілософської та психолого-педагогічної категорії.

Виклад основного матеріалу. Дослідження проблеми фрормування професійної ідентичності опирається на історичний досвід фрілософського осмислення проблем самосвідомості, пізнання людиною самої себе. У такому контексті враховується фрілософрське розуміння як сукупність низки теоретичних і методологічних установок, що визначають спрямованість наукового пошуку у вирішенні поставлених у межах дослідження завдань. Так, із фрілософської позиції почуття ідентичності дає змогу особистості зрозуміти, ким вона $€$, і поєднувати різні вияви багатогранності особистості, що виникають під час соціальних інтеракцій з іншими людьми в різних ситуаціях. Людське Я розглядається як складна система, в якій поєднується безліч Я-образів, кожен із яких відображає особливості поведінки особистості, фокуса пізнавальної діяльності, специфріку психічних реакцій у різних ситуаціях соціальної взаємодії.

Теоретичне осмислення дослідження ідентичності базується на наявних напрацюваннях у різних царинах гуманітаристики. Історична еволюція проблематики ідентичності на різних їі рівнях простежується в фрілософських, психологічних і соціологічних наукових пошуках (Е. Еріксон, 3. Фройд та ін.). 
Розгляд проблеми ідентичності необхідно розпочинати 3 термінологічного аналізу цього поняття. Незважаючи на те що термін «ідентичність» досить широко використовується в наукових дослідженнях та існує достатня кількість його визначень, психолого-педагогічне значення цього поняття потребує уточнення. Для позначення особливостей дефініції «ідентичність» необхідно визначити її сутність у зарубіжній і вітчизняній науці. Як доцільно зазначають Г. Ложкін та Н. Волянюк, концепт ідентичності переживає перманентну проблематизацію. Феномен ідентичності інтерпретують і реінтерпретують, виявляють нові аспекти і грані цього явища, вбудовують його в нові дисциплінарні простори й теоретичні контексти [4, с. 125]. Тому проблема ідентичності є досить складною та багатогранною, а їі осмислення дає глибше й нюансованіше розуміння суб'єктності індивіда в контексті суспільства та культури й у складних умовах постсучасності.

Етимологічно поняття «ідентичність» походить від латинського слова «іdenticus» та означає «тотожність, збіг двох предметів або понять» [7, с. 256]. Традиційно, введення в науковий (психолого-педагогічний) ужиток поняття «ідентиорікація» пов'язують із діяльністю основоположника психоаналізу 3. Фройда, однак він говорив не про ідентичність як таку, а про поняття «ідентифрікація» (нім. identifizierung), яке розглядав як «уподібнення Я чужому Я, внаслідок якого перше Я в певних ситуаціях поводиться як інше, наслідує йому. Ідентифрікація $€$ важливою фрормою зв'язку з іншими індивідами» [8, с. 282-283]. Однак науковець визнавав соціальну сторону его-ідеалу, а в розвитку ідентичності виокремлював два рівнозначні процеси: біологічний - коли організм стає ієрархічною організацією серед живих органічних систем у життєвому циклі, соціальний - коли організми систематизуються в групи, які географрічно, історично й культурно визначені.

Власне поняття «ідентичність», з появою якого почалося розроблення проблеми ідентичності в психологічних, соціологічних, педагогічних дослідженнях у XX ст., увів Е. Еріксон. Ідентичність він розглядав як відносно тривале, але не обов'язково стабільне сприйняття себе як унікального, когерентного, єдиного в часі. У концепції Е. Еріксона чітко простежується спроба створення цілісного інтегративного підходу до вивчення особистості, що виявляється в розумінні ідентичності як складного особистісного утворення, багаторівневої структури. Автор виокремлює три основні рівні аналізу людської природи (згідно з ідентичністю). На індивідуальному рівні ідентичність $є$ результатом усвідомлення особистістю власної часової протяжності; на особистісному рівні ідентичність $€$ відчуттям власної неповторності, унікальності свого життєвого досвіду, зумовлює певну тотож- ність самому собі; на соціальному рівні ідентичність є особистісним конструктом, який відображає внутрішню солідарність особистості із соціальними, груповими ідеалами і стандартами.

Досліджуючи проблеми ідентичності в інтерпретації психоаналізу, інтеракціонізму й когнітивної психології, А. Антонова зазначає, що в окреслених напрямах досліджень ідентичність визначається як найважливіша характеристика цілісності, самостійності та зрілості особистості; ідентичність $€$ тотожністю самому собі. Володіти ідентичністю означає мати особистісно прийнятий образ себе в усьому багатстві відносин особистості з навколишнім світом; почуття адекватності і стабільності володіння власним Я незалежно від зовнішніх i внутрішніх змін; здатність до повноцінного вирішення завдань, що виникають на кожному етапі розвитку особистості [1, с. 140].

Розглядаючи ідентифікацію як соціально-психологічний френомен диференціації, О. Кікінежді обґрунтовує, що становлення ідентичності полягає в процесі важкого вибору між легко здобутим Я (запозиченим, скопійованим) і Я, яке створюється власними зусиллями і стараннями. На думку науковців, ідентичність є моделлю життя, що дає змогу розділити «Я» і навколишній світ, визначити співвідношення внутрішнього й зовнішнього для особистості, кінцевого й нескінченного, адаптації та самозахисту, упорядкувати різноманітність 3 метою самореалізації [2, с. 300]. Тут убачаємо процесуальний і функціональний характер розглянутого френомена.

Отже, теоретичний аналіз поняття «ідентичність» дає змогу трактувати їі розуміння як феномена, що має динамічний і структурний характер, пов'язаний із безперервним процесом розвитку особистості. Аналізуючи проблеми ідентичності, по-перше, необхідно враховувати, що формування ідентичності $є$ взаємопов'язаною сукупністю виборів, за допомогою яких особистість приймає особисті цілі, цінності, переконання. По-друге, розвиток ідентичності не є лінійним процесом, оскільки може розвиватися в прогресивному та регресивному напрямах. І, по-третє, ідентичність розвивається протягом усього життя.

У межах міждисциплінарних досліджень ідентичність розглядається як константність, тотожність особистості, у якій є три ключові складники:

1) психофрізіологічна ідентичність, що позначає єдність і спадкоємність фрізіологічних і психічних процесів організму людини;

2) соціальна ідентичність, що відображає сукупність властивостей, за допомогою яких індивід стає «соціальною одиницею», членом певного суспільства або групи;

3) особиста ідентичність (або егоідентичність), що передбачає послідовність у визначенні життєвих пріоритетів, у постановці та здійсненні різних 
цілей, позиціонуванні себе як особистості, яка усвідомлює свою самість.

У сучасній зарубіжній і вітчизняній науці категорію ідентичності доцільно розглядати як фрілософський, психологічний і соціальний феномен. Відмінною особливістю категорії ідентичності $€$ їі «міждисциплінарність». Єдина позиція науковців полягає в тому, що ідентичність має певну структуру, ознаки й розглядається в контексті взаємодії двох компонентів - особистісного та соціального, які безпосередньо залежать один від одного.

Здійснений короткий аналіз розуміння соціальної та особистісної ідентичності дає змогу безпосередньо перейти до визначення поняття «професійної ідентичності». Аналізуючи підходи до проблеми ідентичності, варто зазначити, що підстави для виокремлення профресійної ідентичності як самостійного психологічного поняття випливають зі змісту й логіки теоретичного та експериментального дослідження особистісної й соціальної ідентичності, яке здійснив Ю. Поварьонков. Науковець зазначає, що виокремлення професійної ідентичності $€$ закономірним процесом послідовної диференціації поняття «ідентичність», оскільки в основі цього процесу враховуються особливості їі елементів. Для професійної ідентичності такими $€$ профресійні цінності й мотиви, професійна Я-концепція та позиція, професійні установки й переконання [5, с. 11]. Непряме підтвердження можливості виокремлення професійної ідентичності як самостійного поняття знаходимо й у наукових пошуках А. Ватермана (A. Waterman), який розглядав сфреру профресіоналізації як одну 3 найзначущих для формування ідентичності в процесі життєдіяльності особистості [9, с. 350]. Професійна ідентичність завжди розвивається в умовах цілком певного професійного співтовариства, 3 яким особистість себе ідентифікує, приймаючи його цінності, норми, правила.

Еволюція наукової думки породила безліч теоретико-методологічних поглядів на дослідження профресійної ідентичності, а тому необхідно визнати перспективність їх взаємозв'язку, оскільки лише в комплексі вони відображають багатогранну картину реальності. Ціннісним підґрунтям теоретико-методологічного синтезу є цінність людини, а інтегрованою методологією дослідження професійної ідентичності - антропологія професій (особливий методологічний аспект дослідження проблем людини у сорері професійної діяльності) [6, с. 8]. У теорії й методології антропології професійна ідентичність розглядається як основа самосвідомості членів професійних груп і спрямовується на вивчення життєвого світу професіоналів «зсередини», на дослідження прихованих особистісних і соціальних процесів, специфіки життєвого світу й ідентичності суб'єктів, що виконують специорічну профресійну функцію. У межах дослідження важливим $€$ розгляд профресійної ідентичності з позиції антропології соціономічних (допомагаючих) профресій, які передбачають спілкування типу «людина - людина».

У межах антропології соціономічних професій профресійна ідентичність майбутніх бакалаврів іноземної мови як об'єкт наукового аналізу визначається як сукупність двох «контурів» ії тотожності - внутрішнього й зовнішнього. Внутрішній контур професійної ідентичності $€$ тотожністю самому собі, своїй психіці, світогляду, цінностей, відчуттів, а зовнішній - тотожністю соціальному оточенню, його принципам, нормам, особливостям професійної діяльності.

Висновки. Отже, у межах дослідження ідентичність розглядаємо як певний особистісний «багаж», що охоплює уявлення особистості про себе, комплекс власних відчуттів, переживань і сприйняття; це процес самопізнання й саморозуміння. Ідентичність набувається, змінюється особистістю протягом усього життя, перебуває в динаміці або в стагнації. Позитивність чи негативність цієї динаміки залежить від сукупності фрізіологічних, психологічних, соціальних критеріїв.

Водночас проблема професійної ідентичності в освітньому середовищі ЗВО заслуговує на окреме вивчення, оскільки в цьому середовищі уможливлюється детальний аналіз усього ланцюга фрормування цього процесу в майбутніх бакалаврів іноземної мови: мотивації вибору професії, становлення студентів з позиції профресійного самовизначення, постановки професійних цілей тощо. Отже, припускаємо, що професійна ідентичність $€$ одним із найважливіших механізмів особистісного освоєння соціальної дійсності студентами. Дефріцит професійної ідентичності не лише дезінтегрує інтрасуб'єктні механізми саморегуляції особистості студентів, а й спричинює зниження необхідного для профресійної самоповаги рівня. Саме тому в межах дослідження орормування професійної ідентичності майбутніх бакалаврів іноземної мови розглядаємо як цілеспрямовану активність у межах навчально-професійної діяльності, яка характеризується усвідомленням важливості обраної профресії та $€$ інструментом досягнення певних життєвих цілей.

Перспективи подальших наукових розвідок убачаємо у висвітленні особливостей використання освітнього контексту професійної підготовки майбутніх бакалаврів іноземної мови як середовища для фрормування професійної ідентичності.

\section{БІБЛІОГРАФІЧНИЙ СПИСОК:}

1. Антонова Н.В. Проблема личностной идентичности в интерпретации современного психоанализа, интеракционизма и когнитивной психологии. Вопросы психологии. 1996. № 1. С. 131-143.

2. Кікінежді О.М. Ідентифікація як соціально-психологічний френомен диференціації статі : дис. ... 
докт. психол. наук : 19.00.07 / Нац. пед. університет ім. М.П. Драгоманова. Київ, 2012. 422 с.

3. Кононов І.Ф. Концепція ідентифрікації та ідентичності в психоаналізі: Зиґмунд Фройд та Ерік Еріксон. Вісник Луганського національного університету імені Тараса Шевченка. Серія «Соціологічні наукц». 2013. № 23 (3). С. 5-27.

4. Ложкін Г.В., Волянюк Н.Р. Професійна ідентичність в контексті маргінальної поведінки суб'єкта. Соціальна психологія. 2008. № 3. С. 123-130.

5. Поваренков Ю.П. Психологическая характеристика профессиональной идентичности субъекта труда. Вестник КГУ им. Н.А. Некрасова. Серия «Педагогика. Психология. Социальная работа. Ювенология. Социокинетика». 2014. № 3 (20). С. 9-16.
6. Романов П.В., Ярская-Смирнова Е.Р. Мир профессий как поле антропологических исследований. Этнографрическое обозрение. 2008. № 5. С. 3-17.

7. Сучасний тлумачний словник української мови: 100000 слів / укл. Н.Д. Кусайкіна, Ю.С. Цибульник ; за заг. ред. В.В. Дубічинського. Харків : Школа, 2009. $1008 \mathrm{c}$.

8. Фройд 3. Вступ до психоаналізу = Einfuhrung in die Psychoanalyse: лекції зі вступу до психоаналізу з новими висновками / пер. 3 нім. П. Таращук. Київ : Основи, 1998. 709 с.

9. Waterman A. S. Identity development from adolescence to adulthood: An extension of theory and a review. Development psychology. 1982. V. 18. № 3. P. 341-358. 